\title{
Physiological Analysis of Orchid Chlorophyll against Odontoglossum ringspot virus Infection
}

\author{
Mahfut $^{1, *}$, Irni Yuni Minarni ${ }^{2}$, Sri Wahyuningsih ${ }^{1}$, Tundjung Tripeni Handayani ${ }^{1}$ \\ ${ }^{1}$ Department of Biology, Faculty of Mathematics and Natural Sciences, Universitas Lampung, Indonesia; ${ }^{2}$ Undergraduate Student, \\ Department of Biology, Faculty of Mathematics and Natural Sciences, Universitas Lampung, Indonesia
}

Received: July 21, 2021; Revised: October 23, 2021; Accepted: November 6, 2021

\begin{abstract}
Orchids (Orchidaceae) are one of the most popular ornamental plants having diverse flower shapes and colors. They are vastly applied as cut flowers, potted plants, and garden elements. Infectious diseases are still a major obstacle in the cultivation of orchids in Indonesia. Odontoglossum ringspot virus (ORSV) is one of the most widely reported viruses that infect orchids worldwide, including Indonesia. This research was done by mechanically injecting the virus on Phalaenopsis amabilis and Dendrobium Salaya Fancy. This study aimed to determine the symptoms of the disease, plant resistance, and chlorophyll content. The results showed that each orchid had severe disease symptoms, the incidence of both orchids was 80\%, and Phalaenopsis amabilis reaction was more susceptible than Dendrobium Salaya Fancy that showed tolerant response to ORSV. Physiological response analysis also showed that the content of chlorophyll A,B, and total Dendrobium Salaya Fancy was higher $(0.35 \pm 0.02 ; 0.29 \pm 0.05$; $0.63 \pm 0.05)$ than Phalaenopsis amabilis $(0,18 \pm 0.0 ; 0.31 \pm 0.06 ; 0.48 \pm$ 0.04 ) respectively, after viral infection. This proves that Phalaenopsis is the most susceptible type of orchid virus compared to Dendrobium.
\end{abstract}

Keywords: selection of resistance; analysis of chlorophyll; orchid; ORSV

\section{Introduction}

Orchidaceae are ornamental plants that have a high aesthetic value (Mose et al., 2020), because they have a variety of colors and flower shapes. For that, high demands of markets on orchids have been raised in the form of cut flowers and potted plants (Mahfut et al., 2016). One of the obstacles in cultivating orchids is infectious diseases that affect flower quality. Orchids can be infected with 50 types of viruses (He et al., 2019), including Odontoglossum ringspot virus (ORSV) (Pai et al., 2019). The virus is an important type that attacks orchids and is popular in the world.

ORSV, also known as Tobacco mosaic virus orchid strain (TMV-O), belongs to the genus Tobamovirus and the family Virgaviridae (Forterre et al., 2017). There is very little information about ORSV infection in Indonesia. The virus is reported to be able to infect Phalaenopsis and Dendrobium orchids in West Java, Central Java, East Java, Banten, Yogyakarta, and Bali (Mahfut et al., 2016). ORSV infection causes damage to chlorophyll and affects the growth and development of orchids.

Efforts to protect orchids against viral infections need to be carried out to reduce the spread and preserve orchids in Indonesia. The initial stage of protection is considered through observing symptoms to determine the type and nature of a disease (He et al., 2017; Ko et al., 2020). This data is then used in determining plant resistance. In addition, chlorophyll analysis was also carried out, and so the physiological response of plants due to viral infection was collected.

This study was conducted to distinguish plant responses in the form of disease symptoms, plant resistance, and chlorophyll content between Phalaenopsis amabilis and Dendrobium Salaya Fancy against ORSV infection. The results of this study are expected to provide information about the response and level of resistance of orchids to ORSV infection, and it could be used as a reference for the right type of orchid to be cultivated in disease endemic areas or there has been a history of previous ORSV infection.

\section{Materials and Methods}

\subsection{Plantlet Acclimatization}

This study used two orchid species, Phalaenopsis amabilis and Dendrobium Salaya Fancy on six replicates. Plantlets were immersed in a fungicide Benlate solution, with active ingredient Benomyl (2 grams/l water) for 20 minutes and then planted in plastic pots containing sterile of moss media (Mahfut et al., 2021). Orchids were well cared for before treatment in a green house.

\subsection{Virus Inoculation}

The inoculum used was prepared from inoculation of the Magelang isolate virus on tobacco plants that had been previously analyzed (Mahfut et al., 2016). The inoculum was then mechanically inoculated. The initial stage of inoculation is to weigh 1 gram of viral inoculum, then

\footnotetext{
* Corresponding author e-mail: mahfut.mipa@fmipa.unila.ac.id.
} 
grind in a sterile mortar by adding $10 \mathrm{ml}$ of $0.01 \mathrm{M}$ phosphate buffer solution (pH 7) (w : v = $1: 10)$. Before being inoculated, 100 mess of carborundum powder was sprinkled on the upper surface of the leaves, then the virus was applied to the two youngest leaf surfaces that were fully opened. After the virus sap dries, the carborundum that remains attached to the leaf surface of the test plant was cleaned by spraying sterile water (Mahfut et al., 2016).

\subsection{Observation of Infection Symptoms}

The results of the inoculation test on plants were noted for variations in symptoms and incubation time. Observations were made every three days for one month to determine the response among host plants that were more quickly infected with symptoms of the disease. ORSV inoculation on each host plant was carried out at different times depending on the fast or slow growth of the plant and indicated whether or not the number of leaves was sufficient.

\subsection{Plant Resistance}

Determination of disease resistance criteria for various types of plants against ORSV infection was based on several factors, including symptoms of viral infection and the percentage of disease incidence. Analysis of plant resistance was used to determine the development of the observed disease, namely disease incidence. The incidence of disease is carried out by calculating the scale of damage (\%) of the disease that appears on the host plant. Plant resistance was grouped into very resistant, resistant, moderately resistant, tolerant, susceptible, and very susceptible, following the method of Dwipa et al. (2018).

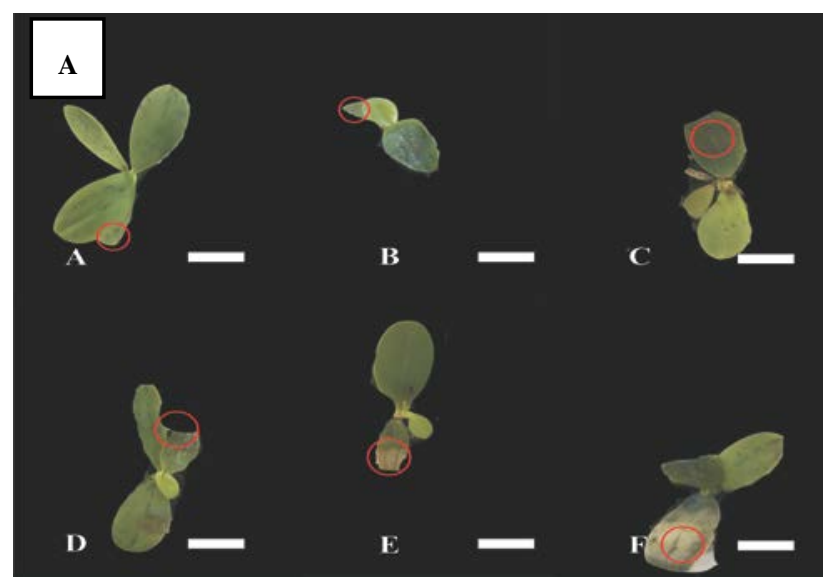

Figure 1. Symptoms of virus infection on (A) Phalaenopsis amab

\subsection{Plant Resistance Analysis}

The results of the analysis of plant resistance to ORSV infection were based on variations in symptoms, incubation times, and disease incidence. The results of the analysis showed that the level of resistance is very susceptible to symptoms of very severe infection. Meanwhile, Dendrobium Salaya Fancy showed a level of resistance that was tolerant to a fairly severe variety of symptoms, but not as severe as the symptoms of infection in Phalaenopsis amabilis.

\subsection{Chlorophyll Content Test}

This test was carried out following Sedjati et al. (2020) using a spectrophotometer. For measuring chlorophyll content, the sample was applied an orchid leaf that had been identified as infected with ORSV. In the first step, 1 gram of treated orchid leaves were weighed, the leaves had been removed, then crushed with a mortar and added 10 $\mathrm{ml}$ of ethanol. The solution was filtered with Whatman paper no. 1 and put into a flakon, then tightly closed. Sample solution and standard solution (ethanol) $1 \mathrm{ml}$ were put into different cuvettes. Furthermore, absorption readings were carried out with a UV spectrophotometer at wavelengths $(\lambda) 648 \mathrm{~nm}$ and $664 \mathrm{~nm}$, the measurements were carried out three times for sample replication.

\section{Results}

\subsection{Observation of Infection Symptoms}

The response of plants after virus inoculation showed that ORSV could infect all types of host plants with variations in symptoms and different incubation times. The results showed that in general the response began to appear about 2-3 weeks after inoculation. The symptoms showed necrotic Phalaenopsis amabilis, while Dendrobium Salaya Fancy showed necrotic and mosaic symptoms. Variations in response to symptoms of viral infection in both host plants are shown on (Figure 1).

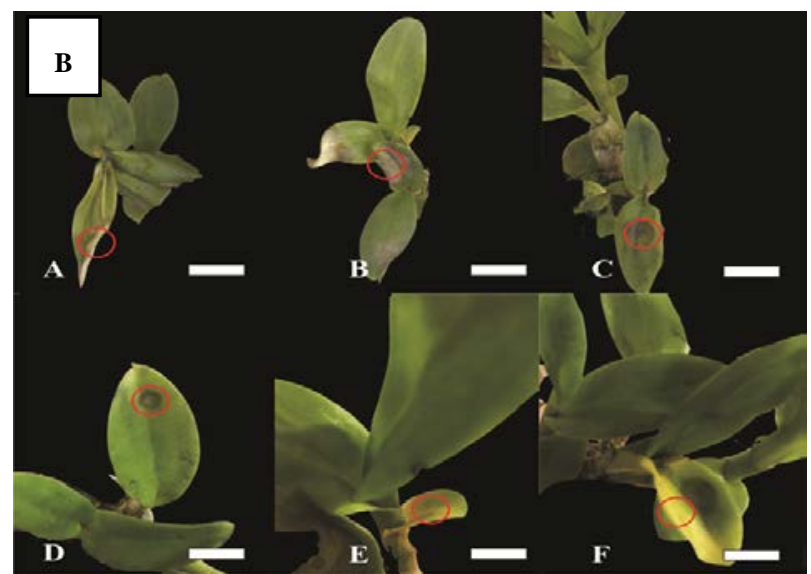

and (B) Dendrobium Salaya Fancy. Bar $=1 \mathrm{~cm}$

\subsection{Chlorophyll Content Test}

The results of the physiological response analysis showed that the chlorophyll A, chlorophyll B, and chlorophyll total content of Dendrobium Salaya Fancy was higher than Phalaenopsis amabilis after being infected with the virus. The complete test results for the content of chlorophyll on both types of host plants for 30 days after ORSV inoculation are shown in Table 1. 
Table 1. Tukey's test of chlorophyll A, B, total content of two types of host plants 30 days after inoculation

\begin{tabular}{llll}
\hline Treatment & Type of & \multicolumn{2}{l}{ Species of Host Plant } \\
\cline { 3 - 4 } & Chlorophyll & $\begin{array}{l}\text { Phalaenopsis } \\
\text { amabilis }\end{array}$ & $\begin{array}{l}\text { Dendrobium } \\
\text { Salaya Fancy }\end{array}$ \\
\hline \multirow{2}{*}{ Control } & Chlorophyll A & $0,17 \pm 0$ & $0,37 \pm 0$ \\
& Chlorophyll B & $0,24 \pm 0,01$ & $0,28 \pm 0$ \\
& Chlorophyll Total & $0,41 \pm 0,01$ & $13,9 \pm 13,27$ \\
\hline \multirow{2}{*}{$\begin{array}{llll}\text { Virus } \\
\text { Inoculated }\end{array}$} & Chlorophyll A & $0,18 \pm 0,01$ & $0,35 \pm 0,02$ \\
& Chlorophyll B & $0,31 \pm 0,06$ & $0,29 \pm 0,05$ \\
Total of & Chlorophyll Total & $0,48 \pm 0,04$ & $0,63 \pm 0,05$ \\
Average & Chlorophyll B & $0,28 \pm 0,04$ & $0,29 \pm 0,03$ \\
& Chlorophyll Total & $0,45 \pm 0,025$ & $7,27 \pm 6,66$
\end{tabular}

Note: The values followed by the same letter are not significantly different at the 5\% level. Chlorophyll A: HSD Cell [.05] = 0.05. HSD Columns $[.05]=0.02$. Chlorophyll B: Values followed by the same letter are not significantly different at the 5\% level. HSD Cell $[0.05]=0.12$. HSD Columns $[.05]=0.06$. Total Chlorophyll: HSD Cell $[0.05]=26.86$. HSD Columns [.05] $=14.5$

The homogeneity of Levene's test variance at 5\% significance level showed that the variance of the samples of the two host plants was homogeneous $(\mathrm{P}=0.201>0.05)$. Analysis of variance at the $5 \%$ level of significance showed that the virus treatment had no significant effect on the chlorophyll a content of the host plant $(\mathrm{P}=1>0.05)$, but the type of plant had a significant effect on the chlorophyll a content $(\mathrm{P}<0.0001)$. Thus, the interaction between virus inoculation and plant species did not significantly affect the chlorophyll a content $(\mathrm{P}=1>0.05)$. The content of chlorophyll A after virus inoculation with two types of host plants is shown in (Figure 2).

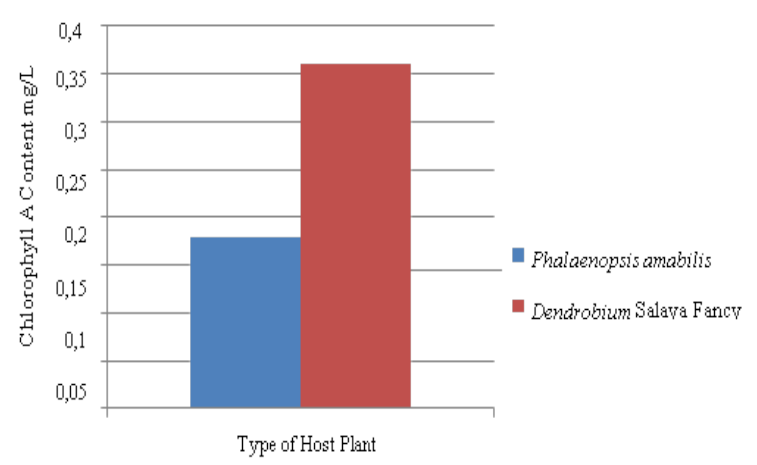

Figure 2. Curves of chlorophyll A content after virus inoculation in two types of host plants

Chlorophyll B is one of the parameters that affect plant metabolism through photosynthesis. The homogeneity of Levene's test variance at $5 \%$ significance level showed that the variance of the samples of the two host plants was homogeneous $(P=0.076>0.05)$. Analysis of variance at $5 \%$ significance level showed that the virus treatment $(\mathrm{P}=0.15>0.05)$ and plant species $(\mathrm{P}>0.05)$ had no significant effect on chlorophyll B levels, respectively. Likewise, the interaction between virus inoculation and plant species did not significantly affect the chlorophyll B content $(\mathrm{P}>0.05)$. Virus inoculation and plant species did not significantly affect chlorophyll B. ORSV inoculation on chlorophyll B content on Phalaenopsis amabilis and Dendrobium Salaya Fancy is shown in (Figure 3).

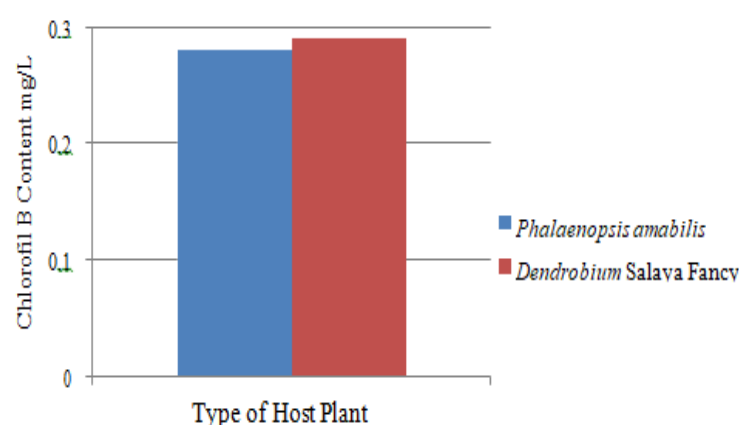

Figure 3. Curves of chlorophyll B content after virus inoculation in two types of host plants

The results of the total chlorophyll content test in both host plant samples also showed homogeneity of the Levene test variance at the level of significance 5 $(\mathrm{P}=0.224)$. The results showed that the virus treatment had no significant effect $(\mathrm{P}=0.34)$ and the type of plant also had no significant effect on the total chlorophyll content $\underline{(P=0.32)}$ in the analysis of variance at $5 \%$ significance level.

Likewise, the interaction between virus inoculation and plant species did not significantly affect the total chlorophyll content $(\mathrm{P}=0.33)$. ORSV virus inoculation, plant species and interactions on host plants did not significantly affect total chlorophyll. ORSV virus inoculation on total chlorophyll content in Phalaenopsis amabilis and Dendrobium Salaya Fancy is presented in (Figure 4).

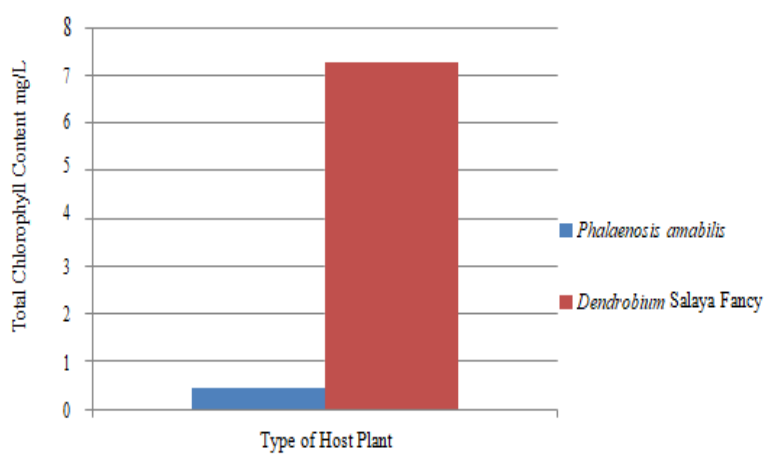

Figure 4. Curves of total chlorophyll content after virus inoculation in two types of host plants

\section{Discussion}

The symptomatic response of ORSV in host plants shows a wide range of symptoms on the examined host plants Phalaenopsis amabilis and Dendrobium Salaya Fancy. Based on the results of the virus inoculation on the two orchids did not show symptoms until the $30^{\text {th }}$ day, so reinoculation was necessary. Then, reinoculation is performed and observed again until symptoms can be seen. Phalaenopsis amabilis showed necrotic symptoms on the 18th day. Observations continued until day 30 and showed worsening necrotic symptoms. In a previous study of Mahfut et al. $\left(2020^{\mathrm{a}}\right)$, it was also known that ORSV infection in Phalaenopsis sp. showed necrotic symptoms on $23^{\text {rd }}$ day.

Dendrobium Salaya Fancy also showed necrotic symptoms on the $15^{\text {th }}$ day. Necrotic symptoms in Dendrobium were shown more rapidly than Phalaenopsis. Based on the observation of symptoms up to day 25, necrotic symptoms turned into a mosaic indicating that 
ORSV infection in Dendrobium was getting worse. In previous studies, it was known that ORSV infection in Dendrobium sp. also appeared necrotic and mosaic symptoms on $15^{\text {th }}$ and $23^{\text {rd }}$ day (Mahfut, 2020; Mahfut et al., 2020 ${ }^{\mathrm{a}}$; Mahfut et al., 2020 ${ }^{\mathrm{b}}$; Mahfut et al., 2021).

The results of disease incidence analysis showed that each host plant had the same response that the disease incidence was $>40 \%$ and disease infection was found. This proves that the inoculation of ORSV on the whole host plant was successful. In previous research (Mahfut, 2020), it is also known that ORSV inoculation in Phalaenopsis sp. and Dendrobium sp. showed an incidence of disease $>40 \%$ and found the presence of disease infection.

Based on the results of the study, it is known that the host plant Phalaenopsis amabilis which shows a very susceptible level of resistance with very severe symptoms of infection. Meanwhile, Dendrobium Salaya Fancy orchid showed a tolerant level of resistance with a fairly severe variation of symptoms, but not as severe as the symptoms of infection in Phalaenopsis amabilis. This means that Phalaenopsis amabilis orchids are more susceptible to ORSV than Dendrobium Salaya Fancy.

Previous research (Mahfut, 2020) reported that Phalaenopsis is a highly susceptible host orchid plant and most susceptible to ORSV. In other research (Mahfut et al., 2020 ; Mahfut et al., 2020 ; Mahfut et al., 2021), it was also known that the plants Phalaenopsis amabilis, P. small Red White Lips x, D. nindii, D. kyosimori, D. liniae, $D$. schulerii had a response, i.e. are susceptible to ORSV.

Chlorophyll content analysis aims to determine the chlorophyll content in the host plant (Jaelani et al., 2016; Alananbeh et al., 2018; Saeed, 2019). Result of Tukey's test at the 5\% significance level showed that two host plants, namely Phalaenopsis amabilis and Dendrobium Salaya Fancy, had a significant effect only on plant species but had no significant influence on viral treatment on chlorophyll A. The content of chlorophyll B in the leaves of Dendrobium Salaya Fancy was not much different from the content of chlorophyll B on Phalaenopsis amabilis leaves. This shows that the plants Dendrobium Salaya Fancy and Phalaenopsis amabilis have the same level of resistance, which is very susceptible to diseases not only caused by ORSV virus but can be caused by other factors such as fungi, bacteria, nutrients found in the media.

Total chlorophyll content in Dendrobium Salaya Fancy orchid leaves is relatively higher than the total chlorophyll content in Phalaenopsis amabilis orchid leaves. This indicates that the Dendrobium Salaya Fancy orchid is more resistant than the Phalaenopsis amabilis orchid to disease. Chlorophyll is a green pigment found in chloroplastide. In general, chlorophyll is found in leaf mesophyll cell chloroplasts, i.e. in palisade parenchyma cells and parenchyma sponge cells. In chloroplasts, chlorophyll is present in the gamma thylakoid membrane. In higher plants, the types of chlorophyll are chlorophyll A and chlorophyll B. Under normal circumstances, the proportion of chlorophyll A is much greater than that of chlorophyll B (Sedjati et al., 2020).

According to the chlorophyll data in this study, it was found that the chlorophyll data on Dendrobium Salaya Fancy plants are more than Phalaenopsis amabilis plants because seen morphologically, Phalaenopsis amabilis orchid plants have more severe symptoms than
Dendrobium Salaya Fancy. It is possible that the leaf mesophyll tissue in Dendrobium Salaya Fancy is not damaged by the virus, and can produce more chlorophyll for photosynthesis. Therefore, it can be concluded that Dendrobium Salaya Fancy is more resistant to ORSV virus or other viruses than Phalaenopsis amabilis. Data on chlorophyll B and total chlorophyll in both host crops are stated to be statistically similar because usually the amount of chlorophyll B is less than that of chlorophyll A (Jaelani et al., 2016; Sedjati et al., 2020). Virus treatment and plant species interactions did not significantly affect the two host plants, so further testing was not performed. Therefore, it can be concluded that Dendrobium Salaya Fancy have a higher level of resistance than Phalaenopsis amabilis.

\section{Conclusion}

The results showed that the indicator crops and the host crops had quite severe disease with various symptoms. Each crop had the same response, the indicator crop had a disease incidence of $>40 \%$ i.e. $75 \%$ while the host crop with a disease incidence of $>40 \%$ i.e. $80 \%$. Indicator and host plant responses to ORSV are highly susceptible, except that Dendrobium Salaya Fancy orchid host plants have a tolerant response to ORSV. The results of physiological response analysis showed that the content of chlorophyll A, B, and total Dendrobium Salaya Fancy were higher $(0.35 \pm 0.02 ; 0.29 \pm 0.05 ; 0.63 \pm 0.05)$ than Phalaenopsis amabilis $(0.18) \pm 0.0 ; 0.31 \pm 0.06 ; 0.48 \pm$ 0.04 ) respectively, after being infected with the virus. This proves that Phalaenopsis is the most susceptible type of orchid virus compared to Dendrobium.

\section{References}

Alananbeh KM, Bouqellah NA, Harbi MRA and Ouf SA. 2018. The Efficacy of Photosensitizers on Mycelium Growth, Mycotoxin and Enzyme Activity of Alternaria spp. Jordan J Biol Sci., 11(5): 499-510.

Dwipa I, Syarif A, Suliansyah I, Swasti E. 2018. West Sumatra Brown Rice resistance to Brown Planthopper and Blast Disease. Biodivers J., 19(3): 893-898.

He J, Lim RMP, Dass SHJ and Yam TW. 2017. Photosynthetic acclimation of Grammatophyllum speciosum to growth irradiance under natural conditions in Singapore. Bot Stud., 58(1): 58

He Z, Dong T, Wu W, Chen W, Liu X and Li L. 2019. Evolutionary Rates and Phylogeographical Analysis of Odontoglossum ringspot virus Based on the 166 Coat Protein Gene Sequences. Plant Pathol J., 35(5): 498-507.

Jaelani LM, Limehuwey R, Jurniadin N, Pamungkas A, Koenhardono ES, and Sulisetyono A. Estimation of Total Suspended Sediment and Chlorophyll-A Concentration from Landsat 8-Oli: The Effect of Atmospher and Retrieval Algorithm. J Technol Sci Educ., 27(1): 9-16.

Ko SS, Jhong CM and Shih MC. 2020. Blue Light Acclimation Reduces the Photoinhibition of Phalaenopsis aphrodite (Moth Orchid). Int J Mol Sci., 21(17): 61-67.

Mahfut. 2020. Identification and Detection Odontoglossum ringspot virus on Native Orchids Collection of Nurserys in Java, Indonesia. Proceedings of ICAISD Conference. University of Bina Sarana Informatika. West Java, Indonesia. 
Mahfut, Anggreiny A, Wahyuningsih S, Handayani TT and Sukimin. 2020 . Identification of Disease and Efforts to Protect Native Orchid Plants Against Bacteria Infection in Liwa Botanical Garden. Proceedings of ICAISD Conference. University of Bina Sarana Informatika. West Java, Indonesia.

Mahfut, Indrianto A, Somowiyarjo S and Daryono BS. 2020 Molecular phylogeny of orchids mycorrhiza isolated from native tropical orchids in Indonesia. Malays J Microbiol., 16(1): 68-72.

Mahfut, Joko T and Daryono BS. 2016. Molecular Characterization of Odontoglossum ringspot virus (ORSV) in Java and Bali, Indonesia. Asian J Plant Pathol., 10(1-2): 9-14.

Mahfut, Shafira H, Wahyuningsih S, Handayani TT and Sukimin. 2021. Identification of Virus Infection on Native Orchid in Liwa Botanical Garden. Proceedings of ICASMI Conference. University of Lampung. Lampung, Indonesia.
Mose W, Daryono BS, Indrianto A, Purwantoro A and Semiarti E. 2020. Direct Somatic Embryogenesis and Regeneration of an Indonesian orchid Phalaenopsis amabilis (L.) Blume under a Variety of Plant Growth Regulators, Light Regime, and Organic Substances. Jordan J Biol Sci., 13(4): 509-518.

Pai H, Jean WH, Lee YS, Chang YCA and Lin SL. 2019. Genome-wide analysis of small RNAs from Odontoglossum ringspot virus and Cymbidium mosaic virus synergistically infecting Phalaenopsis. Mol Plant Pathol., 21(2):188-205.

Saeed AK. 2019. Photo-protective Measurements of Almond Oil on UVB Irradiated Mouse's Skin and Cyclin D1 Expression. Jordan J Biol Sci., 12(4): 395-401.

Sedjati S, Pringgenies D and Fajri M. 2020. Determination of the Pigment Content and Antioxidant Activity of the Marine Microalga Tetraselmis suecica. Jordan J Biol Sci., 13(1): 55-58. 